\title{
Architecture as a pathway to reconciliation in post-earthquake Christchurch
}

\author{
Simon Te Ari Prendergast, Daniel K. Brown \\ Victoria University of Wellington, New Zealand \\ School of Architecture \\ teari@toa.net.nz | Daniel.Brown@vuw.ac.nz
}

\begin{abstract}
This community-based and culturally-situated design research project reflects on issues of community empowerment and activism through speculative design meant to provoke discourse within the wider New Zealand community. As design-led speculative architectural research, it reaches beyond the confines of professional practice. It challenges the norms of contemporary New Zealand architecture by investigating new architectural approaches to explicitly reflect the cultural identity of New Zealand Mãori. The devastating earthquakes of September 4, 2010 and February 22, $201 \mathrm{I}$ destroyed much of Christchurch. While a terrible tragedy, it also opened up the city for fundamental community based discussion. The idea of a post-colonial not just a post-earthquake city emerged, driven by Maori design and planning professionals following the leadership of local elders. The situated community for this designled research investigation is the Ngāi Tahu iwi (Māori tribe) of Ōtautahi / Christchurch. Ngai Tahu professionals in Ōtautahi / Christchurch developed key design aspirations pertaining to the future architecture and urban design of the new city. The city rebuild offered an opportunity to present a Ngāi Tahu vision that reflected its place identity in the new city. The site for this design research investigation is the Ngāi Tahu owned King Edward Barracks, within the Ōtautahi / Christchurch central business district. This traditional Mãori settlement site had been covered with a disparate collection of urban colonial buildings, several of which were destroyed or damaged in the earthquakes. If this Ngāi Tahu owned site (and the city as a whole) is to be rebuilt, is there an opportunity for its architecture to reflect Ngāi Tahu, rather than Eurocentric models? And if so, how might such a design embody Māori and Ngāi Tahu identity, while enhancing New Zealanders' awareness of traditional Māori design, values, and customs - all within the context of a contemporary urban fabric?
\end{abstract}

Keywords: community projects, post-earthquake Christchurch, narrative architecture, Māori identity, speculative architecture.

\section{To cite this article:}

Prendergast, S. T. A., Brown, D. K. (2017). Architecture as a pathway to reconciliation in postearthquake Christchurch. The Journal of Public Space, 2(3), Special Issue, I43-I56, DOI: 10.5204/jps.v2i3. 123

This article has been peer-reviewed and accepted for publication in The Journal of Public Space. Please see the Editorial Policies under the 'About' section of the journal website for further information.

This work is licensed under a Creative Commons Attribution - Non Commercial 4.0 International License https://creativecommons.org/licenses/by-nc/4.0/ 


\section{Ka tahuri te riu o Te Waka a Maui ki raro}

To many in Ngāi Tahu the events of February 22, 20II had parallels with another catastrophic event, the fall of Kaiapoi Pā in the 1830s. Kaiapoi Pā, the largest Ngāi Tahu settlement in the South Island, was decimated by the musket-bearing armed forces of Te Rauparaha. One elder said of this event:

\section{"Ka tahuri te riu o Te Waka a Maui ki raro" \\ English translation "The great canoe of Maui has capsized."}

This dramatic saying - likening the defeat of Kaiapoi Pā to the overturning of Maui's Canoe (South Island) - literally suggested that their entire world had been flipped over, irrevocably changed'. The numerous hapū (communities) of Ngāi Tahu came together after this event, to reclaim its mana (prestige), and this event was the birth of a unified Ngāi Tahu identity ${ }^{2}$. In times of great hardship such as this - particularly their entire world flipped over by the Christchurch earthquakes - Maori leaders have looked to the creation of whare whakairo, traditional carved meeting houses that symbolise the Maori universe in architectural built form. These whare establish visual and experiential narratives of collective community identity, bringing members of a tribe together under common ancestry and association with the landscape ${ }^{35}$. In the design-led experiment undertaken in this research investigation, the whare whakairo was used as a mnemonic device, integrated with the allegorical program of a Māori carving school. The principal objective was to examine architecture's ability to recreate a collective sense of Ngāi Tahu belonging and identity for the community. The carvers' school allegorical programme was conceived fundamentally as a Māori Māoriorative (community-based) investigation. The design concepts arose from user and community participation through intense consultation with Ngāi Tahu elders, architects and carvers. The research objective was to create a uniquely indigenous design response to post-earthquake Christchurch.

\section{Research site}

The site for this design-led research investigation, the Ngāi Tahu owned King Edward Barracks within the Ōtautahi / Christchurch central business district (fig. I), had a rich cultural history prior to colonisation. The early tribe Waitaha first established the Puari settlement over 700 years ago on a large island-like area between the modern-day Carlton Mill Corner and the loop in Ōtakaro (Avon River) near the King Edward Barracks site $^{6}$. In the I500s another tribe, Kāti Mamoe, migrated from Te lka a Maui (North Island)

\footnotetext{
' Grey, Sir George. Nga Mahi a Maui. Wellington City Libraries. Accessed I 3 September 2016. http://www.wcl.govt.nz/maori/wellington/mauil.html.

${ }^{2}$ Ngai Tahu 2025. Accessed 5 June 2016. http://ngaitahu.iwi.nz/wpcontent/uploads/2013/06/NgaiTahu_2025I.pdf

3 Brown, Deidre. "The Architecture of the School of Māori Arts and Crafts". Journal of the Polynesian Society. 108, 3 (1999): 24I-76.

${ }^{4}$ Brown, Deidre. Māori Architecture: From Fale to Wharenui and Beyond. Raupo: Auckland, 2009.

${ }^{5}$ Grant, Lionel, and Skinner, Damian. Ihenga: Te Haerenga Hou: The Evolution of Māori Carving in the 20th Century. Auckland: Reed Publishing, 2007.

${ }^{6}$ Christchurch City Council. Christchurch before 1850. The First Peoples Waitaha to European in Christchurch. Accessed 8 Oct. 2016. https://www.ccc.govt.nz/assets/Documents/CultureCommunity/Heritage/christchurch-before 1850-re-printed-june-2009-publications.pdf.
} 
and settled within the Waitaha area, including at Puari before spreading further south. This was followed by the migration of Ngāi Tahu from the north onto Banks Peninsula, into Canterbury and throughout the South Island during the I700s. ${ }^{7}$

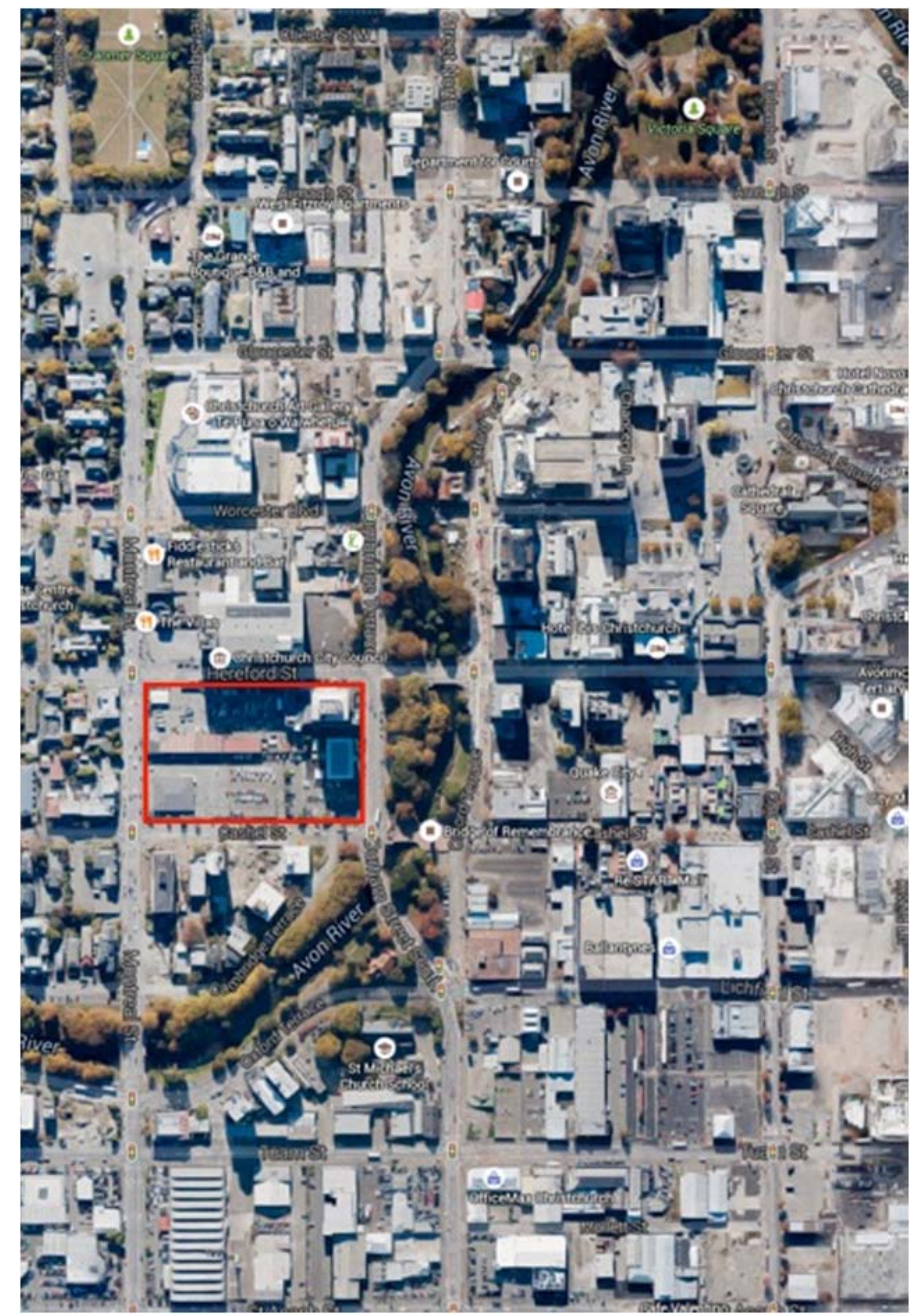

Figure I. Ngāi Tahu owned King Edward Barracks site in Christchurch.

This design research site in the Christchurch central business district was originally a swamp; and so in the new design intervention the site was conceived as a metaphorical swamp (fig. 2) - an eternal reminder of the original landscape for the youth of Ngāi Tahu as well as the inhabitants of Ōtautahi / Christchurch.

While the incorporation of mythology into a community and situated research project may seem antithetical to the traditional view of such projects representing 'real world' situations, Mclntosh et al argue that cultural story-telling is a fundamental attribute of Māori cultural identity taken from a values based perspective ${ }^{8}$.

\footnotetext{
${ }^{7}$ Rawiri Te Maire Tau, "Ngāi Tahu, From 'Better Be Dead and Out of the Way' to 'To Be Seen to Belong,"' in Southern Capital: Christchurch: Towards a City Biography 1850-2000, in Cookson, John and Graeme Dunstall, ed., 233, Christchurch: Canterbury University Press, 2000.

${ }^{8}$ Hanson, Allan. "The Making of the Maori: Culture Invention and Its Logic". American Anthropologist. Vol. 91. n. 4 (1989): 890-92.
} 


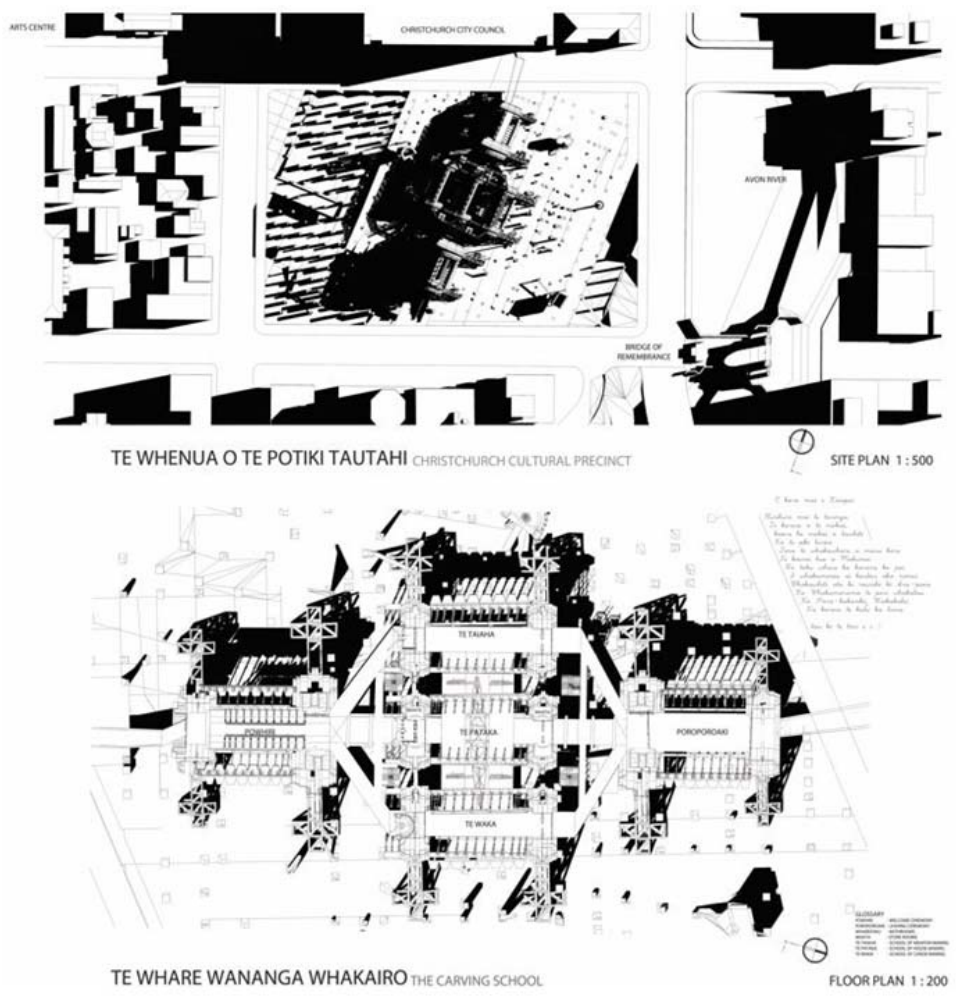

Figure 2. Design site conceived as a metaphorical return to the original swamp.

Local Ngāi Tahu knowledge dictated how one traversed such a landscape, and in this way the original landscape was dependant on Ngāi Tahu storytelling. As part of the Christchurch rebuild, the speculative design concept proposes to excavate this urban site (now destroyed by the earthquakes) below the water table, revealing the lost landscape of the Ngāi Tahu swampland (fig. 3).

The Ngāi Tahu people, as the protectors of both the waterways and the local eel populations, considered Kaitiaki tuna or spring eels sacred; and this allegorical "architectural swamp" represents the materialisation of the realm of the eel gods through architecture. Suspended above the allegorical swamp, the principal structure of the architectural design symbolically represents a traditional hinaki (eel trap; fig. 4); and the "eel" becomes the allegorical path by which the visitor experiences the internal spaces and the progression through the building (fig. 5).

The hinaki design acts as a bridge spanning the artificial swamp and metaphorically linking the past with the future. The reference to the Bridge of Remembrance ${ }^{10}$, a key feature of the Ōtautahi / Christchurch landscape, provides an anchor that references the design within the present.

\footnotetext{
${ }^{9}$ Mclntosh, Alison, Frania Kanara Zygadlo and Hirini Matunga. "Rethinking Maori Tourism”. Asia Pacific Journal of Tourism Research, Vol. 9 , n. 4 (2004): 33I-352.

${ }^{10}$ Christchurch City Libraries. The Bridge of Remembrance. Accessed 23 May 2016.

https://my.christchurchcitylibraries.com/bridge-of-remembrance.
} 


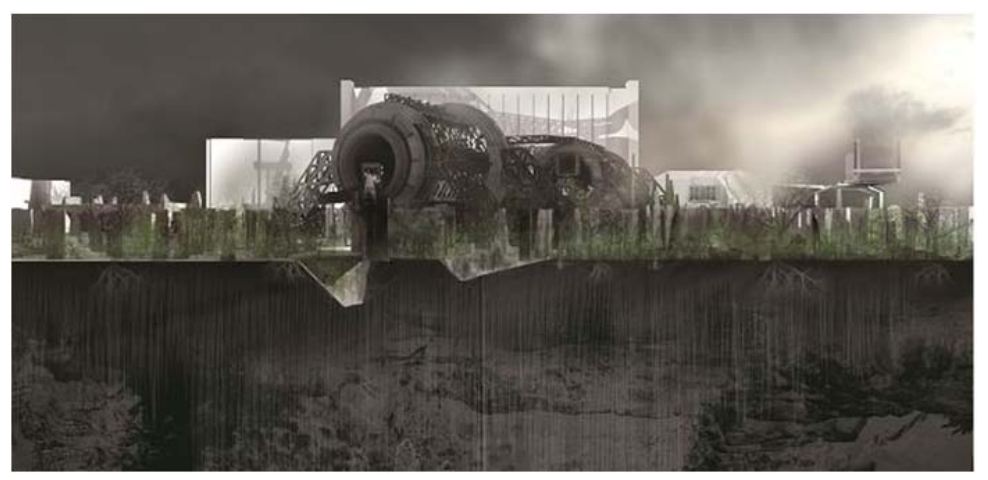

Figure 3. Site section of carvers' school hovering above artificial swamp.

The bridge can be considered a metaphorical pathway to the past, reconnecting people to the landscape and their heritage through the articulation of ritual in the internal spaces.

"Now it is time that gods emerge from things by which we dwell..." "।

\section{- Ranier Marie Rilke}

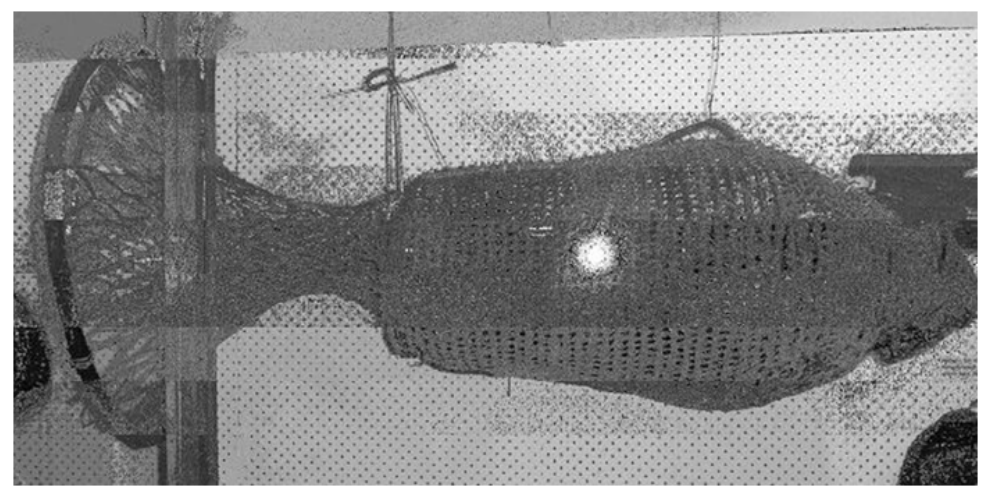

Figure 4 (top). Traditional hinaki (eel trap) from the collection of Okains Bay Māori and Colonial Museum.

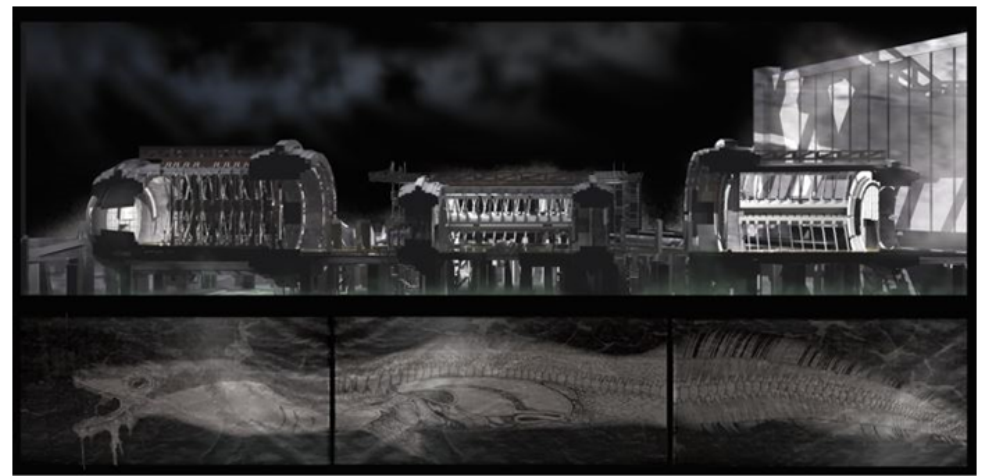

Figure 5 (down). Section demonstrating circular form modelled on traditional hinaki (eel trap) emphasising the importance of eel culture to local Ngāi Tahu.

"The first lines of a poem by Ranier Marie Rilke, 1925, cited by D.F. Krell in Martin Heidegger: Basic Writings, New York: Harper \& Row, 1977: 320. 


\section{Research programme}

According to Trickett ${ }^{12}$, when design research projects are not only community-based but also culturally-situated, applying an ecological perspective can lead to useful multilevel interventions. This culturally-situated research investigation incorporated the ecological perspective by developing a thematic matrix (fig. 6) and an experiential whare whakairo (traditional meeting house) phenomenology matrix (fig. 7) were developed to establish the narrative and sacred progression through the speculative design of an allegorical carving school. These matrices were also used to develop the conceptual thresholds of the whare whakairo and powhiri (welcoming ceremony) into a functioning program for the carving school, integrating the culturally-situated with the community-based.

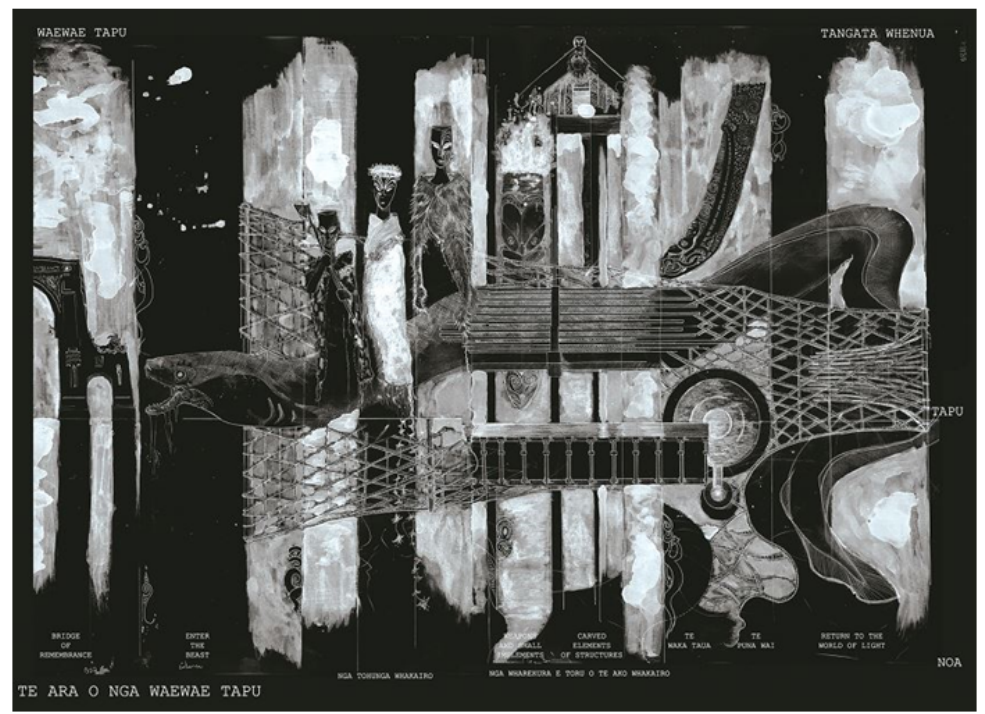

Figure 6. Thematic matrix for the carvers' school.

The identification of public and private spaces is articulated through the progression from waewae tapu (visitors) to tangata whenua (hosts). Once you enter the building and enter into the ritual of the powhiri you are in tapu (sacred) spaces; and it is not until you have passed through and removed the tapu that you can enter into the noa (secular) spaces and exit the building safely. The differentiation between tapu and noa is based upon the importance of that space and its role within the ritual of the powhiri.

\section{Progression from light to dark}

Dr. Pakaariki "Paki" Harrison, renowned tohunga whakairo (expert carver), demonstrates the importance of understanding the procession from light to dark as one progresses through a traditional whare whakairo:

The house is light in the front, expressing warmth and optimism and gradually gets darker to the rear, symbolising the awesome power of night. Those elements that are useful and friendly to man are in the front and those that are hostile or indifferent are at the back. The subtle changes from darkness to light have been created to illustrate in visual

\footnotetext{
12 Trickett, Edison. "Multilevel Community-Based Culturally Situated Interventions and Community Impact: An Ecological Perspective". American Journal of Community Psychology. Vol. 43 (2009), n. 3-4: 257-66.
} 
metaphor the creation genealogies of Te Kore (the void), Te Po (the night) and Te Ao Marama (the world of light). This extra dimension imposes a grander design on the total format, capturing the emotional context of these perceptions and superbly embodying the Māori myth of creation. ${ }^{13}$

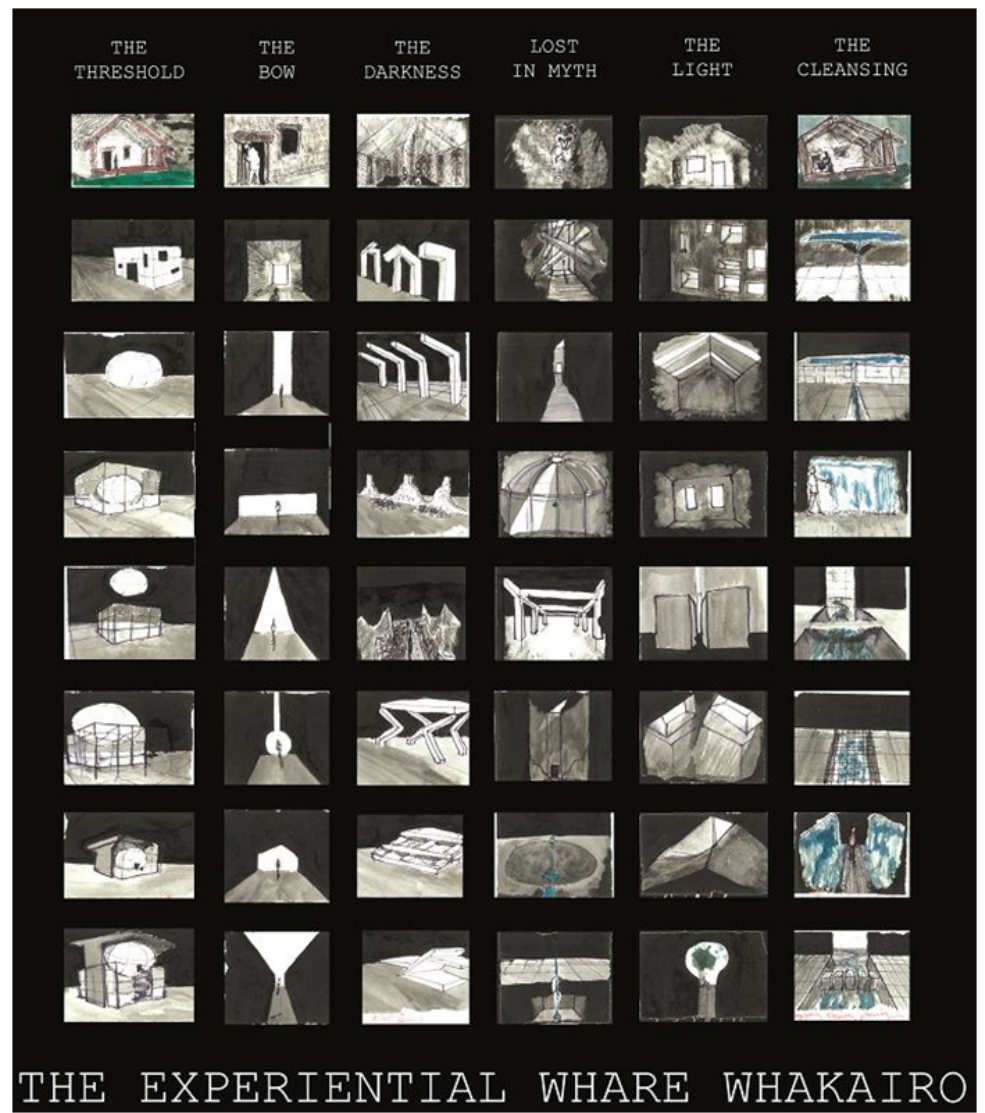

Figure 7. Experiential whare whakairo phenomenology matrix for the carvers' school.

In this way, the metaphorical whare whakairo tells the community the tale of the Mãori creation myth, the emergence of life from the void of darkness. The house itself may be seen as the embodiment of a common ancestor, his koruru (carved head) presented at the apex of the bargeboards where another important ancestor stands as a tekoteko (fully carved figure). The maihi (bargeboards) at the front of the house are his arms, which end in raparapa (fingers). The porch area is known as the roro (brain), and the inside is the poho (belly). The symbolic passage for living members of the tribe between the world of myth and the world of history is the doorway to the interior of the house, traditionally recognised in all meeting houses as a dangerous tapu threshold and boundary between two cosmological orders. ${ }^{14}$

\footnotetext{
${ }^{13}$ Paki Harrison, cited in Ranginui Walker, Paki Harrison: Tohunga Whakairo: The Story of a Master Carver, Auckland: Penguin Books, 2009: 154.

${ }^{14}$ Neich Roger, Tiwai Amoamo, and Tuhe Tupene, "The Complementarity of History and Art in Tutamure Meeting-House, Omarumutu Marae, Opotiki," Journal of the Polynesian Society 93, no. I(I984): 5-38.
} 


\section{Sacred spaces}

Like the interior of the whare whakairo, in this community-based and culturally-situated design investigation the interior spaces are large and open to allow for multiple interpretations of how the spaces can be used. There are three entrances to the sequential carving spaces that students use, based on the three stages of their education (fig. 8); the first space encountered is for the youngest students and the final space is for the most experienced. These entranceways are framed by glass to explicitly read as sacred thresholds, the light framing the darkness as one passes from one realm to another. For the main entrance powhiri space, a pair of steel columns is reminiscent of traditional poupou (panels representing spiritual connection to ancestors) within the whare whakairo (fig. 9).

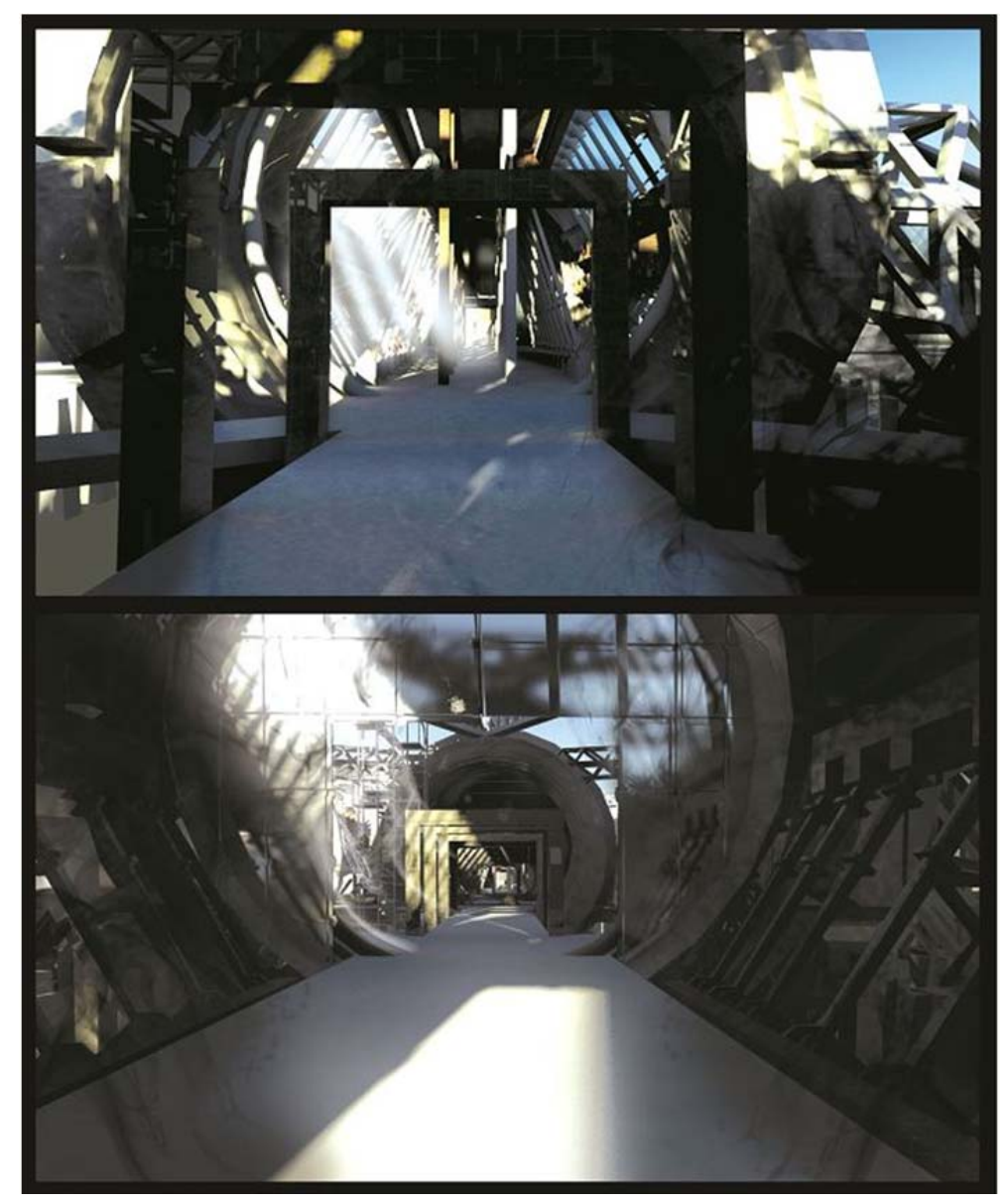

Figure 8. Entry sequences based on stages of a student's education.

It is envisioned that the use here of large steel elements might encourage the carving students to look at other materials and how their stories might also be told through a steel beam or concrete column incorporated into the whare whakairo.

Each of the three entrances has the quarters of the carving master residing above, as a reminder to students of their lessons and as a kaitiaki (guardian) over the students. In this way, the carving master 'inhabitant' is presented to the Māori community as incorporating both real and mythological attributes. These quarters are accessed in the 
same way as the traditional pataka (raised storehouse) - set upon a single pole and accessed by another pole with diagonal cuts carved into it for steps.

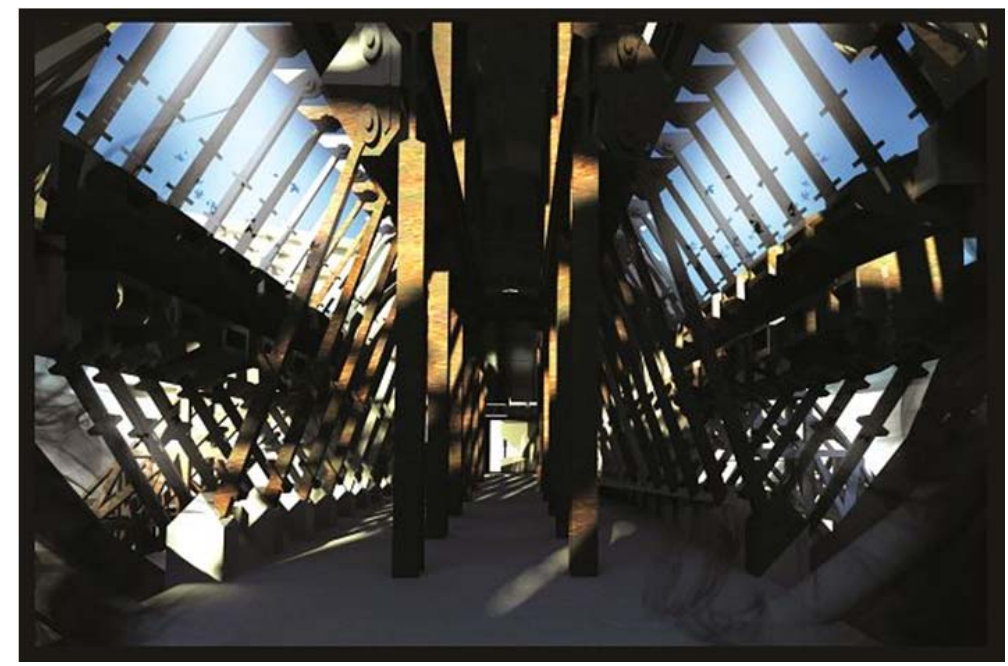

Figure 9. Main entrance with steel columns reminiscent of traditional poupou.

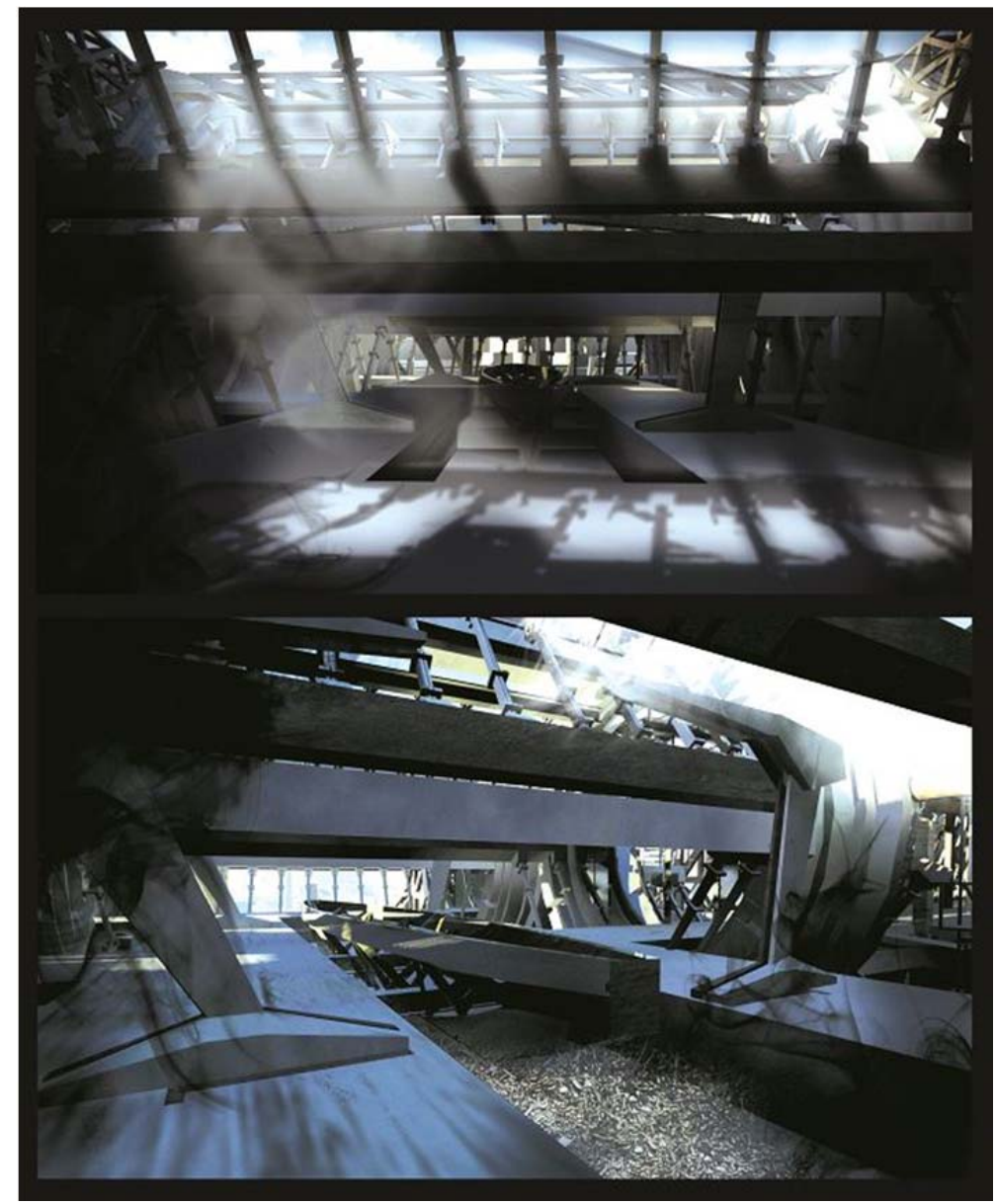

Figure 10. Carving room demonstrating waka carving. 
For the carving of waka in this structure, large timber logs are to be "floated" below the structure and lifted into the waka carving area (fig. 10). Once the waka is hulled out and carved, the waka can be lowered back down into the "swamp." The many wood chips that accumulate below the waka fall down into the "swamp," changing the landscape over time. In this traditional way, the sacred carving chips are returned to the landscape as an offering to the gods for the safe travel of the waka. The return of the building materials to the natural landscape exemplifies an culturally-situated ecological framework for the project (refer to Trickett).

\section{Community involvement in the project}

The primary author was a key part of hui held by Ngāi Tahu elders and design professionals to discuss how they could contribute to the future Christchurch, following the words of Ngāi Tuahuriri elder Te Ari Pitama: "Kia atawhai ki te iwi" - "To care for the people." A key premise was that the city would welcome the people, and would share the identity of the tangata whenua (host) - which became the basis of the design. In the development of the design, critical considerations pertaining to the sacred role of the powhiri were discussed with Ngāi Tahu elders to ensure everything presented was "tika" (correct). At their request the author attended and participated in powhiri rituals on the author's own marae, to gain first-hand knowledge at the "feet" of whanau elders.

From these conversations arose the design-led culturally-situated research idea that the future public buildings and urban spaces needed to accommodate Ngāi Tahu ritual. Ngāi Tahu elders outlined the importance of being able to "speak to the landscape of their ancestors" during such processes (another important component of the "ecological framework'), by retaining viewsheds to prominent landscape features, incorporating native plantings, acknowledging historic trails and mahinga kai (customary food gathering sites), and allowing for the use of architectural spaces for cultural purposes. It was proposed that culturally-situated ideas arising from Ngā Aho ritual and culture could be incorporated into the overall blueprint for the entire Christchurch rebuild of a new city.

\section{Empowerment and activism}

To elicit culturally appropriate and authentic design concepts, a speculative scenario was proposed to the elders of how one would conduct an "Opening Ceremony" at the completion of the central city rebuild. Where in the city would such a ritual begin, and where would it end? How could these future spaces accommodate such a ritual and become the backdrop to this momentous occasion? When entering a whare whakairo, a powhiri (welcoming ceremony) is held. An opening ceremony begins at a gateway ${ }^{15}$, so where would the gateway to the city be? Karakia (communications with the gods) focus on the poutokomanawa (the carved central pole of a wharenui or meeting house). So where would the poutokomanawa of the city reside? This conversation with the cultural community of Ngā Aho around the hypothetical scenario of the "opening ceremony" ritual was a successful design and communication tool to frame conversations with iwi

\footnotetext{
${ }^{15}$ The Marae - meeting place. In New Zealand in History. Accessed 25 July 2016. http://historynz.org/maori5.html.
} 
elders, to ask the right questions, and to develop cultural knowledge for architectural design considerations.

To convey these concepts to a wider audience, Ngāi Tahu joined with Ngā Aho and Manaaki Whenua to organise a two day workshop inviting all the key organisations and professionals involved in the rebuild, including architects and engineers, construction companies and project managers, government and council officials. This was a proactive step to present an explicitly Māori vision for the future, and to develop relationships with the future-builders of Ōtautahi / Christchurch. From these discussions two key spaces in the central city were identified where the Ngāi Tahu narrative could be expressed architecturally:

- The Ōtākaro / Avon River can be interpreted as the city's tāhuhu (main ridge pole of a wharenui) - connecting spaces, reflecting the landscape connection, and acknowledging Ngāi Tahu values for mahinga kai;

- Victoria Square was an important Ngāi Tahu kāinga (settlement) where Ngāi Tahu lived for generations, and a place of early Ngāi Tahu interaction and trade with European settlers. Simultaneously, it can be seen as an acknowledgement of Queen Victoria, the Treaty, and the courts where the Ngāi Tahu treaty claim was discussed. Part of this complex was returned to Ngāi Tahu in the Settlement. Its location and proximity to the river would make it a key "Gateway" and ideal place to initiate the narrative of the new city.

University-based research projects such as this can play a significant role in stimulating the development of interdisciplinary practices and the emergence of community ${ }^{16}$.

Collaborative community-based research should not be dismissed simply because it might appear biased in favour of the client groups with which researchers work. Instead, it should be embraced as a practice that, when well done, can help clients to better identity and address problems, practices, and policies that affect their lives and their communities." 17 . The collaborative process can lead to important policy changes, but to do so, it is essential that it contributes to community empowerment, ie, "the capacity to set priorities and control resources that are essential for increasing community selfdetermination" 18 . The impact of this research investigation is evidenced by its significant contribution to enhancing Ngāi Tahu community empowerment. Ngāi Tahu became equal partners in the rebuild, and as part of their role as equal partners in the rebuild, Ngāi Tahu provided the culturally-situated narrative that underpinned and guided some of the community-based decision-making in the Central City Blueprint and Recovery Plan. This also established a process for engagement where Ngāi Tahu professionals, designers and planners, worked within the Blueprint team "shoulder to shoulder" to translate the culturally-situated aspirations of Ngāi Tahu elders into tangible community-based design outcomes that helped to accelerate the process of engagement with Ngāi Tahu. This community and iwi engagement process was followed in other key architectural design

\footnotetext{
${ }^{16}$ Siedlok, Frank, Paul Hibbert, and John Sillince. "From Practice to Collaborative Community in Interdisciplinary Research Contexts”. Research Policy. Vol. 44, n.I (20I5): 96-I07.

${ }^{17}$ Shdaimah, Corey, Roland Stahl, and Sanford Schram. Change Research: A Case Study on Collaborative Methods for Social Workers and Advocates. New York: Columbia University Press, 201 I:4.

${ }^{18}$ Himmelman, Arthur Turovh. "On the Theory and Practice of Transformation Collaboration: from Social Service to Social Justice”. In Huxham, Chris, ed. Creating Collaborative Advantage. London: Sage Publications, 1966: 19-43.
} 
projects along the Ōtākaro / Avon River where Victoria Square and Puari and Tautahi (historic Ngāi Tahu sites) are located. Ngāi Tahu elders were engaged to provide cultural knowledge, and a clear process was established early so that their knowledge was a key driver. The design process began with ritual blessings and traditional food that also helped to frame the communal nature of the relationships and engagement.

The newly designed Regional Sciences and Innovation Centre in central Christchurch (figg. II-12) exemplifies this exceptional level of community engagement - where Ngāi Tahu architects were imbedded in design teams to expedite the consultation process and deliver authentic cultural design outcomes.

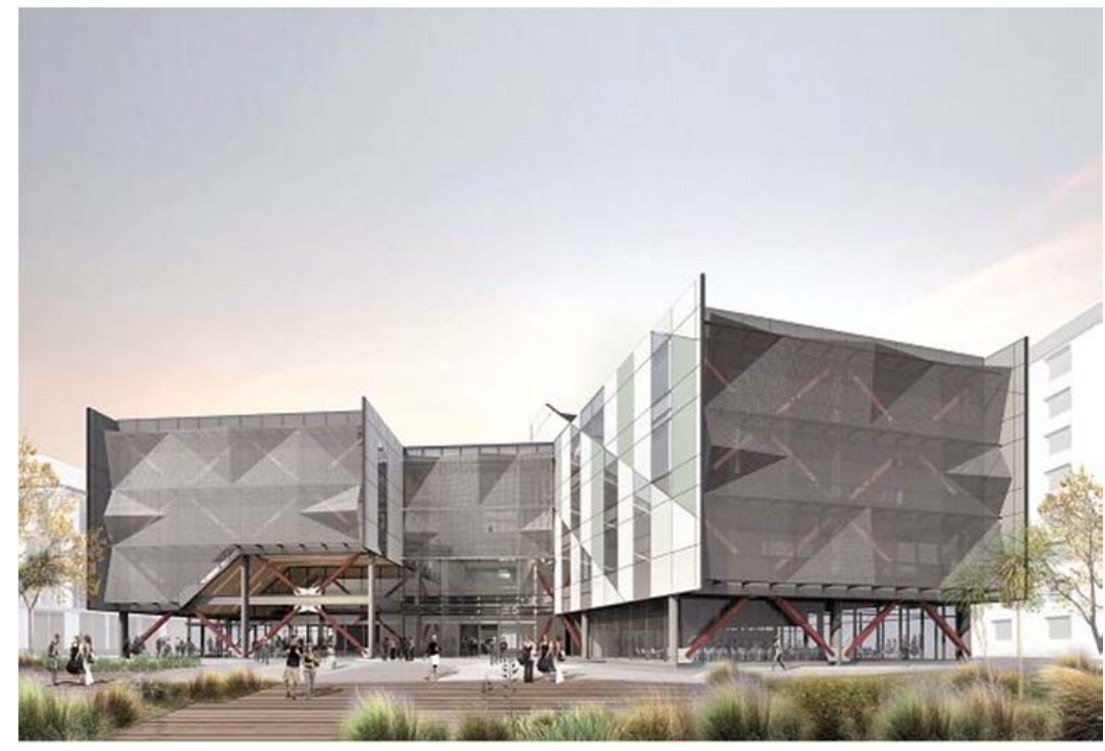

Figure II. The Regional Sciences and Innovation Centre, designed by Jasmax, DJRD and Royal Associates Architects, with Ngāi Tahu architects forming part of the design team (Image courtesy of Jasmax).

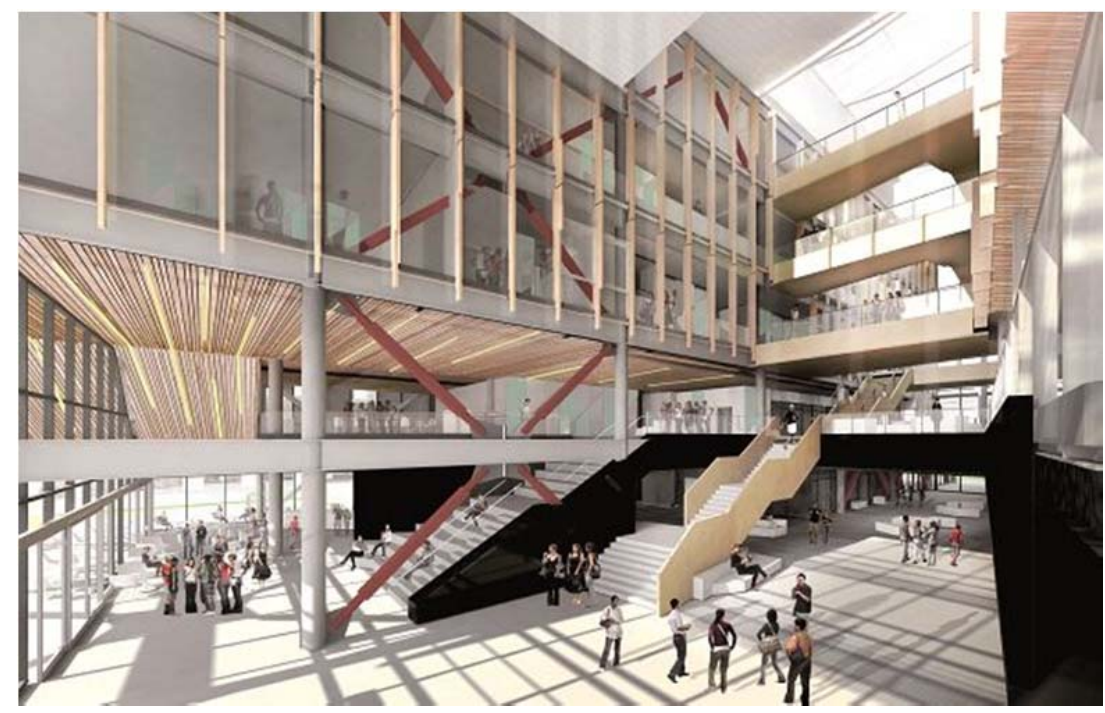

Figure 12. Regional Sciences and Innovation Centre design interior (Image courtesy of Jasmax). 
This design was influenced by the story of Tawhaki ascending the Heavens and establishing the pathway to knowledge. The relationship of the building to the landscape was conceptualised as a tool for learning and connected to the Ngāi Tahu values for mahinga kai (cultural heritage) and kaitiakitanga (guardianship). The Christchurch Rebuild Blueprint also included a proposed Te Puna Ahurea Cultural Centre (figg. 13-14; no longer going ahead) that represented another real opportunity to create a distinctive Ngāi Tahu architectural and programmatic statement.

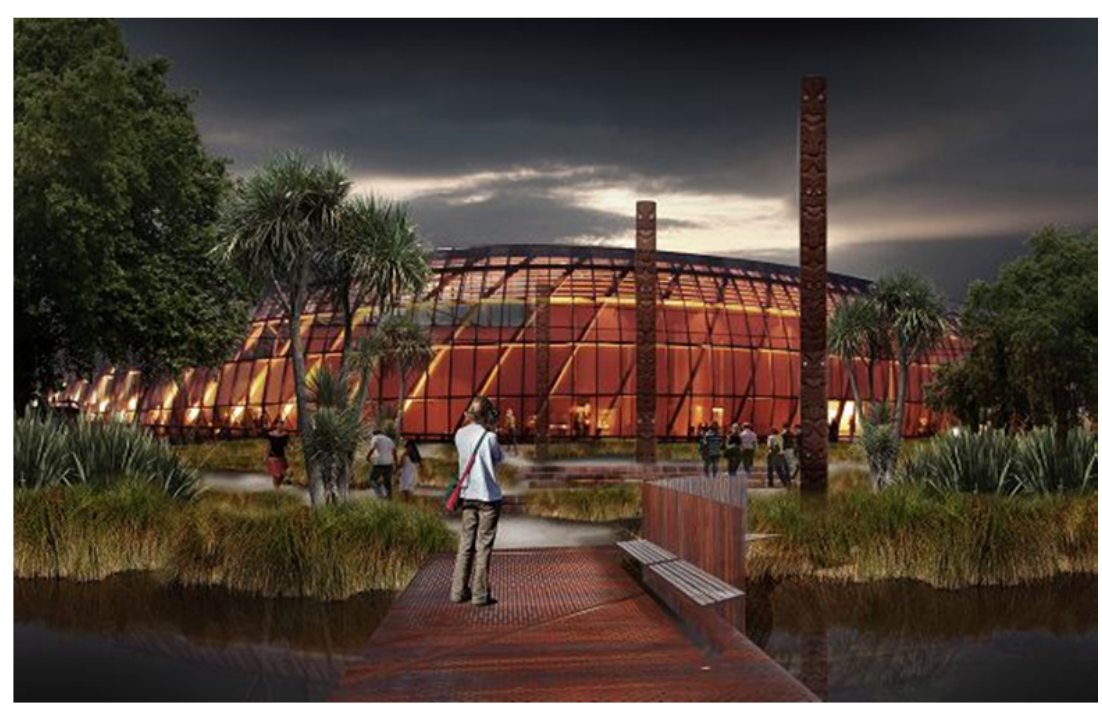

Figure 13. The Te Puna Ahurea Cultural Centre design by Royal Associates (Image courtesy of Royal Associates).

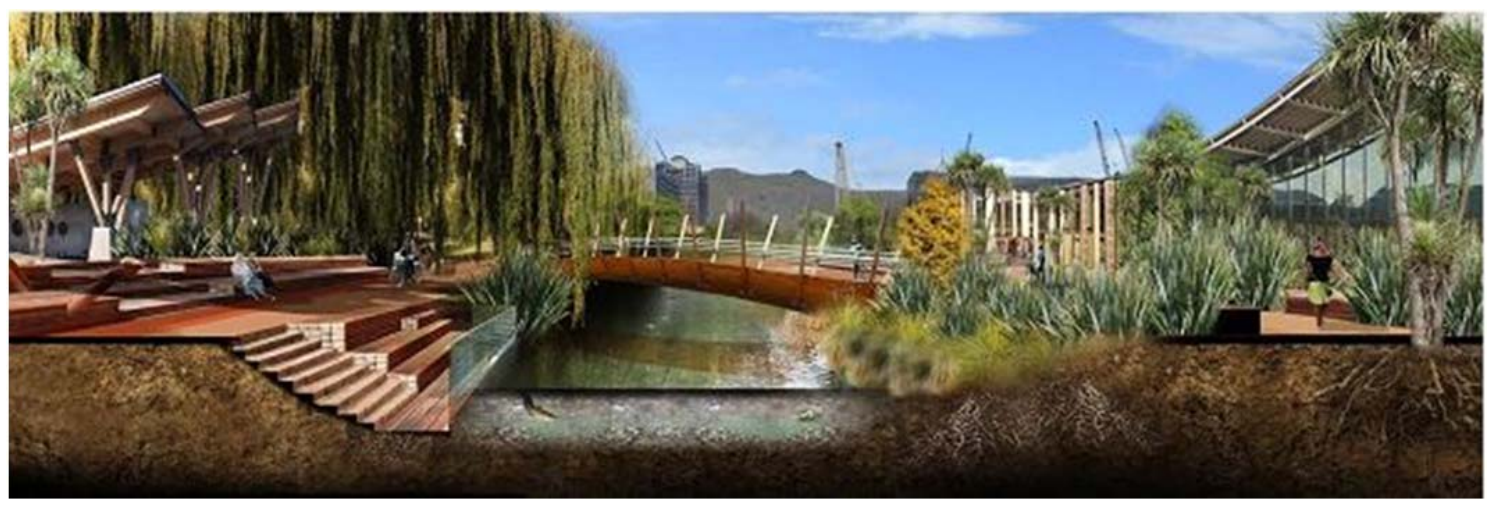

Figure 14. Artist's interpretation of design for Otãkaro / Avon River incorporating Ngai Tahu design aspirations. Produced by Royal Associates Architects (Image courtesy of Royal Associates).

\section{Conclusion}

Architecture as an expression of culture and identity has the power to uplift and unify but it also has the power to oppress and marginalise when groups are excluded from the process. For the past 150 years Ngāi Tahu have lived in a city described as "little England," devoid of an expression of their own culture and values. The opportunity to express Ngāi Tahu identity in the new city was coupled with the realisation and fear that the rebuild could also be a process whereby Ngāi Tahu are "colonised all over again." 
The fact that Ngāi Tahu have had a significant place in many aspects of the rebuild attest to this not being the case with: Ngāi Tahu seen as equal partners with CERA (Canterbury Earthquake Recovery Authority) and CCC (Christchurch City Council); Ngāi Tahu engagement as artists and designers; young Māori trade training and up-skilling; and Ngāi Tahu championing grass-roots and community groups.

This university-based design research investigation played an important role in helping to bridge the gap between Eurocentric community-based and Māori iwi culturally-situated aspirations and propositions. It also helped to cement the role of Te Runanga o Ngai Tahu as a partner to the Christchurch City Council and the Canterbury Earthquake Recovery Authority in the rebuild, and it has demonstrated and reinforced the value indigenous cultures can bring to the restoration of post-disaster cities. This group became involved in the development of the Central City Blueprint and Recovery Plan, to develop further these aspirations for the new city and explore additional opportunities to express this narrative. For many, this was our generation's 'Te Kereme' - a chance to do our part for future generations and have our ancestors and stories acknowledged in the future city, and by successfully coupling community-based and culturally-situated design research, ideas for a successful rebuild were able to actually represent the greater community of Christchurch. 